sies were not very satisfactory, but did support this finding. In this patient urinary excretion of tyrosine, and particularly the phenolic metabolites of tyrosine. was grossly elevated. Although this situation persisted after dietary treatment. some improvement in his behavior was noticed, particularly with respect to the loss of tremor.

The other patient, an 11-year-old girl of low normal intelligence with chronic palmar and plantar keratosis and recurrent pseudoherpetic keratitis, suffered from substrate inhibition of $p$ hydroxyphenylpyruvic acid oxidase when on a normal diet. Resolution of the clinical and biochemical symptoms and disappearance of the inhibition of $p$-hydroxyphenylpyruvic acid oxidase occurred after administration of a diet low in phenylalanine and tyrosine. The fundamental metabolic defect in this patient has not been established, but the findings appear compatible with a defect in hepatic soluble tyrosine aminotransferase.

\section{REFERENCES AND NOTES}

1. Callan, N. J.: Circumscribed palmo-plantar keratoderma. Aust. J. Dermatol., 9: $76(1970)$

2. David, J.-C., Dairman, W., and Udenfriend, S.: Decarboxylation to tyramine: A major route of tyrosine metabolism in mammals. Proc. Nat. Acad. Sci. U.S.A., 71: 1771 (1974).

3. Faull, K. F., Gan, I., Halpern, B., and Danks, D. M.: The use of stable isotopes for the in vivo study of metabolic disorders. Proceedings of the Second International Conference on Stable Isotopes, Oak Brook. Illinois. October 1975 (Argonne National Laboratory, Ill., in press.)

4. Gan, I., Korth, J., and Halpern, B.: Use of gas chromatography-mass spectrometry for the diagnosis and study of metabolic disorders. J. Chromatogr., 93: 435 (1974).

5. Goldsmith. L. A.. Kang, E., Brenfang. D. C., Jimbow, K., Gerald, P., and Baden. 11. P: Tyrosinemia with plantar and palmar keratosis and keratitis. J. Pediat., 83: 798 (1973).

6. Granner, D. K., and Tomkins, G. M: Tyrosine aminotransferase (rat liver). Methods Enzymol., I7(A): 633 (1970).

7. Kakimoto, Y., and Armstrong, M. D: The phenolic amines of human urine. J. Biol. Chem., 237: 208 (1962).

8. Kennaway, N.G., and Buist, N. R. M: Metabolic studies in a patient with hepatic cytosol tyrosine aminotransferase deficiency. Pediat. Res., 5: 287 (1971).

9. Knox, W. F.., and LeMay-Knox, M.: The oxidation in liver of L-tyrosine to acetoacetate through $p$-hydroxyphenylpyruvate and homogentisic acid. Bior chem. J.. 49: 686 (1951).

10. LaDu. B. N.: The enzyme deficiency in tyrosinemia. Amer. J. Dis. Child.. 113: 54 (1967).

11. LaDu, B. N., and Zannoni, V. G.: The tyrosine oxidizing system of liver. II. Oxidation of $p$-hydroxyphenylpyruvic acid to homogentisic acid. J. Biol. Chem. 217: 777 (1955).

12. Louis, W. J., Pitt, D. D.. and Davies, H.: Biochemical studies on a patient with tyrosinosis. Aust. N.Z. J. Med., 4: 281 (1974).

13. Martin. R. B., and Morlino, V. J.: Exchange of carbon bound hydrogen atoms ortho to the hydroxyl group of tyrosine. Science. 150:493 (1965)

14. Medes, G.: A new error of tyrosine metabolism: Tyrosinosis. The intermediary metabolism of tyrosine and phenylalanine. Biochem. J., 26:917 (1932).

15. Scriver, C. R., and Rosenberg, L. E.: Amino Acid Metabolism and Its Disorders, pp. 338-369, (W. B. Saunders Co., Philadelphia, 1973).

16. Udenfriend, S., and Cooper, J. R.: The chemical estimation of tyrosine and tyramine. J. Biol. Chem., 196: 227 (1952).

17. Westmore, R.. and Billson. F. A.: Pseudoherpetic keratitis: Corneal changes in circumscribed palmo-plantar keratoderma. Brit. J. Ophthalmol., 57: 6.54 (1973).

18. Williams, K. M., and Halpern, B.: The use of gas chromatography-mass spectrometry for the diagnosis and study of metabolic disorders. Aust. J. Biol. Sci.. 26: 831 (1973).

19. Williams, K. M., and Halpern, B.: Gas chromatography of amino acids via pyrolysis methylation of neopentylidene trimethylanilinium salts. Ann. Lett., 6: 839 (1973).

20. Scientific Hospital Supplies, Liverpool, England.

21. Sigma Chemical Co.. St. Louis, Mo., U.S.A.

22. Figures for catecholamines were kindly supplied by Professor W. J. Louis, University of Melbourne. Department of Medicine, A ustin Ilospital, using a modification of the trihydroxyindole procedure (12).

23. We would like to thank Professor W. J. Louis and Dr. D. D. Pitt who made earlier studies on $J L$, and Dr. F. A. Billson who referred $P R$ for investigation. Expert technical assistance was supplied by Ian MicNeice and John Korth who ran the GC-MS instruments.

24. In accordance with the Helsinki agreement informed consent from the parents of $P R$ was obtained after full discussion. The Mental Health Department of Victoria, the legal custodians of $J L$, gave consent to these investigations. $J L$ himself willingly agreed to take part in the actual experiments although he is unable to comprehend the ir full implications.

25. This work was supported by grants from The National Health and Medical Research Council of Australia.

26. Requests for reprints should be addressed to: Professor D. M. Danks. Department of Pediatrics, Royal Children's Hospital, Flemington Rd.. Parkville. Victoria 3052 (Australia).

27. Received for publication June 10, 1976

28. Accepted for publication September 22, 1976

\title{
A Comparison of Fasting Plasma Insulin and Growth Hormone Concentrations in Marasmic, Kwashiorkor, Marasmic-Kwashiorkor and Underweight Children
}

\author{
H. ROBINSON, ${ }^{(36)}$, AND D. PICOU \\ Tropical Metabolism Rescarch Unit, University of the West Indies, Kingston, Jamaica, West Indies
}

\section{Summary}

Fasting plasma insulin and growth hormone concentrations were measured in 24 marasmic, 11 kwashiorkor, 16 marasmickwashiorkor, and 4 underweight children. Hormone measurements were made by a special modification of the Hales and
Randle double antibody immunoassay with increased sensitivity in the concentration range $0-25 \mu \mathrm{U} / \mathrm{ml}$. Fasting plasma insulin was low in marasmus, kwashiorkor, and marasmic-kwashiorkor children, and increased to normal levels after recovery. Fasting plasma growth hormone was elevated in all groups during malnutrition and was significantly decreased to normal levels after 
recovery. There were no significant differences in plasma insulin or growth hormone levels between the different clinical types of severe protein energy malnutrition. These hormonal changes in severe protein energy malnutrition are of complex and not fully understood etiology. However, recovered children appear to have a hormonal pattern similar to that described in normal control infants and children.

\section{Speculation}

Abnormal fasting hormone levels in protein energy malnutrition may reflect part of the adaptive mechanism for survival during starvation.

Abnormalities in plasma hormone concentrations have been found in protein energy malnutrition (PEM) and reports on these changes have been conflicting (6). Such inconsistency may be attributed to different methods of hormone assay, diversity of subjects, and varying conditions of study. In addition, different criteria have been used for the diagnosis of each syndrome in malnutrition.

In this study, we sought to define more closely the differences in fasting plasma insulin and plasma growth hormone levels in marasmic, kwashiorkor, and marasmic-kwashiorkor Jamaican children, before and after recovery. We also observed a small group of children who were not severely malnourished and who were classified as underweight. The IVellcome system of classification (34) has been used to assign diagnoses. Plasma hormone concentrations were measured by a modification of the immunoassay method of Hales and Randle (9) which increased the precision and sensitivity at very low concentration ranges.

\section{EXPERIMENTAL PROCEDURES}

\section{SUBJECTS}

According to the Wellcome system of classification (34) malnourished infants with no clinically detectable edema who were less than $60 \%$ of expected weight for age were diagnosed as marasmus. Those with edema who weighed less than $60 \%$ of expected weight for age were classified as marasmic-kwashiorkor. Kwashiorkor children were those with edema who weighed between $60 \%$ and $80 \%$ of expected weight for age. Children who had no edema and whose body weight was between $60 \%$ and $80 \%$ of expected weight for age were diagnosed as underweight. Standards for expected weight for age were based on those published by Jellife (16). Twenty-four marasmic, $11 \mathrm{kwa}$ shiorkor, 16 marasmic-kwashiorkor, and 4 underweight children between the ages of 5.7 and 24 months were studied.

\section{INVESTIGATIONS}

Blood samples from malnourished children were taken after 3-4 days on a maintenance diet containing $112 \mathrm{kcal}$ and $0.9 \mathrm{~g}$ protein/kg/day. Then the children were fed a high caloric diet (providing $250 \mathrm{kcal}$ and $5.7 \mathrm{~g}$ protein $/ \mathrm{kg} /$ day) until they reached expected weight for height (22), when they were considered to have recovered. Blood samples were also taken after recovery. Fasting blood (4 or $8 \mathrm{hr}$ ) was collected in tubes containing EDTA, $2 \mathrm{mg} / \mathrm{ml}$, and immediately centrifuged for $8 \mathrm{~min}$. The plasma was stored at $-20^{\circ}$ until analyzed. Informed consent was obtained for study of all patients.

\section{METHODS}

Insulin Assay. Insulin was measured by a modification (31) of the double antibody method (9) using a commercially available kit (Amersham Radiochemicals). The human insulin standard (potency 23.5 units/mg) was supplied with the kit. The double antibody reagent was diluted 5 times that recommended in the kit, the first incubation phase in the absence of labeled insulin was extended to $18 \mathrm{hr}$, and the second incubation after labeled insulin was added, was shortened to $6 \mathrm{hr}$. These conditions produced a steep standard curve between 0 and $25 \mu \mathrm{U} / \mathrm{m}$. Insulin added to plasma was accurately recovered and dilution of plasma gave reproducible results. EDTA was chosen as the anticoagulant since it was suggested that heparin interferes in the double antibody reaction leading to abnormally high insulin values (10), 11). Preliminary experiments showed that EDTA plasma insulin values agreed closely with serum insulin values. With this assay, the normal adult fasting plasma insulin was $6.3 \pm 0.9$ (range 4.9-7.9) $\mu \mathrm{U} / \mathrm{ml}$.

Growth Hermone Assay. Growth hormone was measured by the double antibody method using iodinated growth hormone supplied by Abbott Laboratories, and double antibody reagent supplied by Wellcome Research Laboratories. The growth hormone standard was kindly donated by the National Institute for Medical Research, Medical Research Council, United Kingdom. Incubation times for both phases were as recommended by Wellcome Research Laboratories. The double antibody reagent was diluted twice that recommended by the supplier.

Glucose Assay. Glucose was measured by the glucose oxidase method (12).

\section{RESULTS}

A comparison of 4- and 8-hr fasting values for plasma insulin, growth hormone, and glucose within each clinical group showed no significant difference and the combined values were therefore used in subsequent analyses. The results are shown in Table 1. Fasting plasma insulin was significantly lower before than after recovery from kwashiorkor. However, the differences in plasma

Table 1. Comparison of fasting plasma insulin and growth hormone concentrations in marasmic, kwashiorkor, marasmickwashiorkor, and underweight children, before and after recovery (4-and 8-hr fasting values combined; mean \pm SEM)

\begin{tabular}{|c|c|c|c|c|c|c|c|c|}
\hline \multirow[b]{2}{*}{ Diagnosis } & \multirow[b]{2}{*}{ Age, ${ }^{1}$ mo. } & \multirow[b]{2}{*}{ Wt/age, $\%$} & \multicolumn{3}{|c|}{ Insulin, ${ }^{2} \mu \mathrm{U} / \mathrm{ml}$} & \multicolumn{3}{|c|}{ Growth hormone, ${ }^{2} \mu \mathrm{g} / \mathrm{liter}$} \\
\hline & & & Malnourished & Recovered & $\begin{array}{c}P \text { val- } \\
\text { ues }^{3}\end{array}$ & Malnourished & Recovered & $P$ values \\
\hline Marasmus & $11.8 \pm 1(24)$ & $49.8 \pm 1.5(24)$ & $2.1 \pm 0.2(20)$ & $3.2 \pm 0.4(17)$ & $\mathrm{NS}^{3}$ & $14.7 \pm 2.1(24)$ & $5.5 \pm 1(17)$ & $<0.001$ \\
\hline Kwashiorkor & $13.8 \pm 1.1(11)$ & $70.3 \pm 1.7(11)$ & $2.0 \pm 0.5(7)$ & $3.8 \pm 0.2(7)$ & $<0.01$ & $18.1 \pm 3.7(10)$ & $3.1 \pm 0.4(7)$ & $<0.005$ \\
\hline $\begin{array}{l}\text { Marasmic- } \\
\text { kwashior- } \\
\text { kor }\end{array}$ & $14.4 \pm 1.1(16)$ & $52.9 \pm 1.2(16)$ & $2.9 \pm 0.4(15)$ & $3.0 \pm 0.5(11)$ & NS & $17.9 \pm 2.2(19)$ & $3.2 \pm 0.8(5)$ & $<0.005$ \\
\hline Underweight & $13.1 \pm 2.7(4)$ & $67.1 \pm 1.7(4)$ & $3.4 \pm 0.8(4)$ & $2.8 \pm 0.5(3)$ & NS & $16.9 \pm 8.1(4)$ & $7.3(2)$ & \\
\hline
\end{tabular}

\footnotetext{
1 Number of subjects are shown in parentheses.

2 Number of observations are shown in parentheses.

${ }^{3}$ Not significant.
} 
insulin values before and after recovery in marasmic, marasmickwashiorkor, and underweight children were not statistically significant. Comparison between the different clinical groups showed no significant differences in fasting insulin levels either before or after recovery.

Fasting plasma growth hormone concentrations were significantly higher in children with marasmus, marasme-kwashiorkor, and kwashiorkor than after recovery. In underweight children plasma growth hormone was higher, but not significantly so, than after recovery. Comparison between clinical groups showed no significant difference in fasting growth hormone concentration either before or after recovery.

\section{DISCUSSION}

\section{INSULIN}

Although several workers have reported low fasting plasma insulin levels in PEM, accurate measurement of values below 10 $\mu \mathrm{U} / \mathrm{ml}$ is not possible when certain immunoassay methods are used. In our experience, the Hales and Randle double antiody method, as adapted for use with he kit from Amersham Radiochemicals, does not consistently detect insulin in the very low concentration range. Our modification of this method utilizes this commercially available kit and satisfies the requirements for sensitive and accurate measurement of plasma insulin in the concentration range $0-25 \mu \mathrm{U} / \mathrm{ml}$.

Hadden (8) in Uganda reported normal values for plasma insulin in kwashiorkor but the lower fasting values in malnourished children found in the present study agree with the results of most workers $(1,13,19,18)$. It is interesting to note that the absolute values reported here are significantly lower, both before and after recovery, than the corresponding values reported in previous studies. This probably reflects the increased sensitivity and accuracy of the modified assay that was used in this study.

Although there are marked structural changes in the acinar pancreas of children dying from severe $\operatorname{PEM}(4,5,7)$ there have been no reports on the morphology or function of the islets cells in PEM. In experimentally induced malnutrition in rats, with marked acinar damage and low plasma insulin concentration, islet morphology appeared normal (28). Furthermore, since the abnormal insulin concentrations after fasting and stimulation in PEM disappear quickly after refeeding it is unlikely that morphologic changes in the islet cells are an important etiologic factor. In severe PEM, low serum insulin values were found to be associated with hypoalbuminemia $(18.1-22.0 \mathrm{~g} / \mathrm{liter})$ and concurrent infection (19). Pimstone et al. (28) carried out intravenous glucose tolerance tests and total body potassium measurements in kwashiorkor patients with or without potassium supplementation. They found significant increases in total body potassium, peak insulin response, insulin "output," and insulin to glucose ratio in the potassium-supplemented group. Another factor that has been postulated to account for the subnormal fasting plasma insulin concentration in malnourished children is an impairment in the gut insulinotrophic mechanism (28). No significant difference was found in plasma insulin concentrations before and after recovery from marasmic-kwashiorkor and marasmus in the present study. This agrees with results from studies in India and Mexico $(15,23)$. The subtle (but nonsignificant) increase in fasting plasma insulin levels may reflect the increase in fasting plasma glucose levels (from 68 to $82 \mathrm{mg} / \mathrm{dl}$ ) which occurs after treatment.

Our finding that fasting plasma insulin was significantly increased in one group, recovered kwashiorkor, questions the accepted opinion that fasting plasma insulin is abnormally low in all syndromes of PEM. It is clear that the fasting level of plasma insulin in malnutrition is of complex etiology, and the paucity of normal values in infants and young children makes it difficult to assess the results found in PEM.

\section{GROWTH HORMONE}

Fasting plasma growth hormone values were significantly higher in marasmic, kwashiorkor, marasmic-kwashiorkor, and underweight children and were significantly suppressed to normal levels in each group after recovery. A comparison showed no significant difference between groups.

The role of growth hormone in severe PEM has been investigated by workers in several parts of the world and the results are conflicting. In four studies of marasmic children the levels of fasting plasma growth hormone were higher on admission than after recovery $(3,24,25,32)$; others found that there was no significant difference in marasmic infants and after 4 weeks of therapy (29). Comparison of values for fasting plasma growth hormone in marasmus and in normal control subjects has been reported by three groups of workers. In the Chilean study, the fasting plasma growth hormone value in marasmus was lower than that in normal control subjects (2). However, the marasmic infants were studied after 10 or more days on an adequate diet and this could well have resulted in depression of the growth hormone levels (25). The study by Raghuramulu and Jaya Rao (29) in older marasmic children showed no significant difference in the fasting plasma growth hormone levels between marasmic and control children. In the South African study the fasting kevel of fasting plasma growth hormone was significantly higher in marasmic children on admission than in age-matched control subjects (25). A hypothesis to explain the different evolution of kwashiorkor and marasmus is partly based on the findings of a raised plasma growth hormone level in the former and a normal level in the latter (17). However, neither the present study nor other published studies $(3,23,33)$ substantiate that the fasting plasma growth hormone concentration is normal in marasmus.

Results of studies in several countries on the fasting level of growth hormone in kwashiorkor are fairly consistent and show that in untreated kwashiorkor the plasma growth hormone level was higher than in partially or fully recovered cases $(2,19.23$, $25,29,33)$. A significant negative correlation between plasma growth hormone and serum albumin has been shown in marasmus (25) and in kwashiorkor (17.19). However, it does not appear that the elevated growth hormone level is related to hypoalbuminemia per se since the former is significantly depressed within $36 \mathrm{hr}$ of milk feeding without alteration in serum albumin level $(3,25)$. Furthermore, intravenous albumin infusion in kwashiorkor patients did not suppress their high plasma growth hormone levels and children with the nephrotic syndrome and hypoalbuminemia have normal levels of growth hormone (3). It has been shown that plasma growth hormone fell to $50 \%$ of its elevated fasting level in malnourished children following a single intragastric feeding of high energy milk protein feed (30). Oral glucose alone did not suppress the elevated fasting levels of growth hormonc in kwashiorkor (27), but abnormalities in the plasma growth hormone concentration and in the plasma aminogram rapidly returned toward normal within 13 days of feeding a diet containing protein and calories (32). It is interesting to note that a highly significant correlation between plasma growth hormone and alanine in kwashiorkor was demonstrated before and after treatment, and between growth hormone and the branched chain amino acids, after treatment (26).

Despite the differences in plasma concentration of insulin and growth hormone, the malnourished child responds to an appropriate dietary regime without hormone therapy (18) and on recovery the hormone pattern appears to be normal.

\section{CONCLUSION}

No significant differences in fasting plasma levels of insulin, growth hormone, and glucose were found between marasmic, kwashiorkor, marasmic-kwashiorkor, and underweight children (Wellcome Classification, 1970 (34)). During malnutrition the fasting plasma insulin level was low and increased after recovery; 
the fasting plasma growth hormone level was high and decreased on recovery.

\section{REFERENCES AND NOTES}

1. Baig, H. A. and Edozien, J. C.: Carbohydrate metabolism in kwashiorkor. Lancet, ii: 662 (1965).

2. Beas, F., Contreras, I., Maccioni, A., and Arenas, S.: Growth hormone in infant malnutrition: The arginine test in marasmus and kwashiorkor. Brit. J. Nutr., 26: $169(1971)$.

3. Becker, D. J., Pimstone, B. L.. Hansen, J. D. L., and Hendricks. S.: Insulin secretion in protein-caloric malnutrition. I. Quantitative abnormalities and response to treatment. Diabetes, 20:542 (1971).

4. Bras, G., Waterlow, J. C., and De Pass, E.: Further observations on the liver, pancreas and kidney in malnourished infants and children. J. Trop. Pediat. 2: 147 (1956).

5. Davies, J. N. P.: The essential pathology of kwashiorkor. Lancet, $i$ : 317 (1948).

6. Gardner, L. I., and Amarcher, P.: In: Endocrine Aspects of Malnutrition. Proceedings of a Symposium (Kroc Foundation, Santa Ynez, Calif., 1973).

7. Gillman, J., and Gillman, T.: In: Perspectives in Human Malnutrition, p. 201 (Grune \& Stratton, New York, 1951).

8. Hadden, D. R.: Glucose, free fatty acid, and insulin interrelations in kwashiorkor and marasmus. Lancet, $i i: 589$ (1967).

9. Hales, C. N., and Randle, P. J.: Immunoassay of insulin with insulin-antibody precipitate. Biochem. J., 88: 137 (1963).

10. Henderson, J. R.: Serum-insulin or plasma-insulin? Lancet, ii: 545 (1970)

11. Henderson, J. R.: Serum-insulin or plasma-insulin? Lancet, ii: 1430 (1971).

12. Hugget, A. St. G., and Nixon. D. A.: Use of glucose oxidase, peroxidase, and o-dianisidine in determination of blood and urinary glucose. Lancet, $i i: 368$ (1957).

13. James, W. P. T., Coore, H. G.: Persistent impairment of insulin secretion and glucose tolerance after malnutrition. Amer. J. Clin. Nutr., 23: 386 (1970).

14. Jaya Rao, K. S.: Evolution of kwashiorkor and marasmus. Lancet, $i$ : 709 (1974).

15. Jaya Rao, K. S., and Raghuramulu, N.: Growth hormone and insulin secretion in protein caloric malnutrition as seen in India. In: L. I. Gardner and $P$. Amacher: Endecrinc Aspects of Malnutsition, pp. 91-98 (The Kroc Foundation, Santa Ynez, Calif., 1973).

16. Jellife, D. B.: In: The Assessment of the Nutritional Status of the Community (with Special Reference to Field Surveys in Developing Regions of the World) (World Health Organization, Geneva, Switzerland, 1966).

17. Kajubi, S. K., and Okel, R. M.: Serum insulin and growth hormone after kwashiorkor. Amer. J. Clin. Nutr., 27: $1200(1974)$.

18. Kerr, D., Ashworth, A.. Picou, D.. Poulter, N., and Seakins, A. Spady, D. and Wheeler, E.: Accelerated recovery from infant malnutrition with high calorie feeding. In: L. I. Gardner and P. Amacher: Endocrine Aspects of Malnutrition, p. 467. (The Kroc Foundation, Santa Ynez, Calif.. 1973)

19. Lunn, P. G., Whitchead, R. G., Hay. R. W., and Baker, B. A.: Progressive changes in serum cortisol, insulin and growth hormone concentrations and their relationship to the distorted amino acid pattern during the development of kwashiorkor. Brit. J. Nutr., 29: 399 (1973).

20. Milner, R. D. G.: Metabolic and hormonal responses to glucose and glucagon in patients with infantife malnutrition. Pediat. Res., 5: 33 (1971).

Copyright (1) 1977 International Pediatric Research Foundation, Inc.
21. Mortimer, C. H., Tunbridge, W. M. G., Carr, D., Yeomans, L., Lind, T., Doy, D. H., Bloom, S. R., Kastin, A., Mallinson, C. N., Besser, G. M. Schally, A. V., and Hall, R.: Effects of growth-hormone release-inhibiting hormone on circulating glucagon, insulin and growth hormone in normal, diabetic, acromegalic, and hypopituitary paticnts. Lancet, $i: 697$ (1974).

22. Nelson, W. E., Vaughan, V. C., and McKay, R. J.: Textbook of Pediatries, Ed. 9 (W. B. Saunders Co., Philadelphia, 1969).

23. Parra, A., Garza, C., Klish, W., Gracia, G., Argote, R. Canseco, L. Cuellar, A., and Nichols, B.: Insulin-growth hormone adaptations in marasmus and kwashiorkor as seen in Mexico. In: L. I. Gardner and P. Amacher: Endocrine Aspects of Malnutrition, p. 31 (The Kroc Foundation, Santa Ynez, Calif., 1973).

24. Parra, A., Garza, C., Garza, Y., Saravia, J., Halewood, C., and Nichols, B.: Changes in growth hormone, insulin and thyroxine values and in energy metabolism of marasmus infants. J. Pediat., 82: 133 (1973).

25. Pimstone, B. L., Barbezat, G., Hansen, J. D. L., Murray, P.: Studies on growth hormone secretion in protein-calorie malnutrition. Amer. J. Clin. Nutr., $21 ; 482$ (1968)

26. Pinstone, B. L., Becker, D. J., Hansen, J. D. L.: Human growth hormone in protein-caloric malnutrition. In: A. Pecile and E. E. Muller: Growth and Growth Hormone. Proceedings of the Second International Symposium on Growth Hormone, Milan, 1971, p. 389 (Excerpta Medica Foundation, Amsterdam, 1972).

27. Pimstone, B. L., Becker, D. J., and Hansen, J. D. L.: Human growth hormone and sulphation factor in protein-caloric malnutrition. In: L. I. Gardner and P. Amacher: Endocrine Aspects of Malnutrition, p. 73 (The Kroc Foundation, Santa Ynez, Calif., 1973)

28. Pimstone, B. L., Becker, D., Weinkove, C., and Mann, M.: Insulin secretion in protein-caloric malnutrition. In: L. I. Gardner and P. Amacher: Endocrine Aspects of Malnutrition, p. 289 (The Kroc Foundation, Santa Ynez, Calif., 1973).

29. Raghuramulu, N., and Jaya Rao, K. S.: Growth hormone secretion in proteincalorie malnutrition. J. Clin. Endocrinol. Metab., 38: 176 (1974).

30. Robinson, H. M. . Cocks, T., Kerr, D., and Picou, D.: Fasting and postprandial levels of plasma infants and growth hormone in malnourished Jamaican children during catch-up growth and after complete recovery. In: L. I. Gardner and P. Amacher: Endocrine Aspects of Malnutrition, p. 45 (The Kroc Foundation, Santa Ynez, Calif., 1973).

31. Rubinson, H. M., and Kerr, D.: The attainment of high sensitivity and precision in the double antibody immunoassay of insulin. (Manuscript in preparation.)

32. Saunders, S. J., Truswell, A. S., Barbezat, G. O., Wittman, W., and Hansen, J. D. L.: Plasma free amino acid pattern in protein-caloric malnutrition. Lancet, $i i: 795$ (1967).

33. Suskind, R., Amatayakul, K., Leitzmann, C., Otson, R.: Interrelationships between growth hormone and amino acid metabolism in protein caloric malnutrition. In: L. 1. Gardner and P. Amacher: Endocrine Aspects of Malnutrition, p. 99 (The Kroc Foundation, Santa Ynez, Calif. 1973).

34. Wellcome Classification.: Lancet, ii: 302 (1970).

35. The authors thank Miss Jennifer Alexander for excellent technical assistance.

36. Requests for reprints should be addressed to: H. M. Robinson, M.D., Tropical Metabolism Research Unit, University of the West Indies, Mona, Kingston 7, Jamaica (W. I.).

37. Received for publication January 22, 1976.

38. Accepted for publication September 22, 1976. 